\title{
Changes in olive oils used as covering in preserves of eggplants (Solanum Melongena) in relation to the time and the condition of storage
}

\author{
By A. de Leonardis*, V. Macciola and M. de Felice \\ Dipartimento di Scienze e Tecnologie Agro-Alimentari, Ambientali e Microbiologiche, \\ Università del Molise, Via De Sanctis, 86100 Campobasso, Italy \\ e-mail: Antomac@hpsrv.unimol.it
}

\section{RESUMEN}

Cambios en aceites de oliva usados como coberturas en la conservación de berenjenas (Solanum Melongena) en relación con el tiempo y las condiciones de almacenamiento.

El uso de aceite de oliva virgen extra como cobertura en conservas alimentarias presenta una serie de problemas que son todavía hoy objeto de estudio. El objetivo de este estudio fue investigar los cambios de algunos parámetros analíticos producidos durante el almacenamiento en aceite de oliva usado como cobertura en la conservación de berenjenas.

Se encontró que el aceite que ha estado en contacto con las berenjenas, sufrió una disminución de los fenoles totales inmediatamente después del tratamiento térmico, afectando a los procesos oxidativos. Se observó asimismo, que en todos los aceites almacenados a la luz variaron significativamente los valores del $\mathrm{K}_{270}$, del $\Delta \mathrm{K}$, de la clorofila y de la proporción de 1,2-DG36/1,3DG36.

PALABRAS-CLAVE: Aceite de oliva - Almacenamiento-Berenjena - Cobertura - Tiempo.

\section{SUMMARY}

Changes in olive oils used as covering in preserves of eggplants (Solanum Melongena) in relation to the time and the condition of storage.

The use of the extra virgin olive oil as covering in food preserves presents some problems and still today object of study. With this research it was investigate the changes of some analytical parameters that occur during the storage in the olive oils used as covering in eggplant preserves.

It was ascertained that in the oils in presence of the eggplants a drastic decrease of the total phenols was verified immediately after the thermal treatment affecting the oxidative processes. Besides it was observed that in all the oils stored under light the values of the $\mathrm{K}_{270} . \Delta \mathrm{K}$, the total chlorophylls and the 1,2-DG36/1,3-DG36 ratio were significantly changed. Time.

KEY-WORDS: Eggplant - Olive oil - Preserve - Storage -

\section{INTRODUCTION}

The vegetables preserved in oil are a typical food of the Mediterranean tradition. The covering oil is of use to isolate the food from the air reducing the development of the aerobic micro-organisms and of the oxidative processes. The oil doesn't develop any bacteriostatic or bactericide direct action and therefore the microbial stability of the food must be got before the its addition (POMPEI, 1978).

The olive oils and some seed oils, above all the sunflower oil, are generally used in this preserves. In the last years some food on the market appeared that exalt in label the use extra virgin olive oil in alternative to seeds oils or other fat. The use of the extra virgin olive oil like covering presents same problems and still an object of study (DE LORENZO, 1997).

It was observed (CUCURACHI, 1966) that same analytical characteristics relative to the extra virgin olive oil significantly changed when the oil was stored in presence of another substance. In preserves of the artichokes, tomatoes, little onions and fish the free acidity increased during the storage and in any cases it was ascertained that the hydrolytic activity was started immediately after the pasteurization (PAGANUZZI et al., 1995).

The observation of the Peroxide Value (P.V.) lead to conflicting conclusions: in some cases it was observed that the P.V. increased in an initial phase and after it stabilized while in other cases the value didn't change in the time (MUCCIARELLA et al., 1997, GOMES et al., 1998).

PAGANUZZI et al. (1995) observed that in same cases the $K_{232}$ index slightly increased while the values found of the $K_{270}$ and the $\Delta K$ were superior to the legal limit imposed for the extra virgin olive oil. The subsequent purification on alumina didn't always render the values of these indexes within the legal limit.

Some authors suggested the possibility to use the analysis of the unsaponifiable fraction (Paganuzzi et al., 1996) or the trans-fatty acid analysis (BIZZOZERO, 1996; CAVALLARO, 1996) to establish the genuineness of the oils. They demonstrated that also these analytical determinations are not suitable parameters to establish the market category of the olive oil used at the moment of the packing.

Not less important are the interactions that occurs between the oil and the preserved food. It was 
ascertained that the foods can release fatty acids that alter the fatty acid profile of the oil and in the covering oil of fish preserves the C20:5 and C22:6 fatty acids were found, as well as an increase of the palmitic and stearic acids (LEONE, 1997).

The shelf life of the olive oil in containers of glass in relation to different conditions of storage are well studied while the literature regarding the same points in the covering oils results rather poor. The intrinsic capacity of the extra virgin olive oil to preserve itself can decrease when this is in presence of another food components. The aim of this research was to investigate the changes of some analytical parameters that occurs in the olive oils during the storage when they are used as covering in eggplant (Solanum melongena) preserves.

\section{EXPERIMENTAL}

\subsection{Material and reagent}

Preparation of the eggplant preserves: The eggplant preserves were prepared directly in the industry of Giacomo lorio in Lucera (FG) and packed in clear-glass jars of the $250 \mathrm{ml}$ capacity with Twist-off cover.

Sampling of the oils: two extra virgin olive oils and one refined oil were used. The extra virgin olive oil, marked like EV1, was taken from the «Bombini Onofrio» oil-mill in Andria (BA). The other extra virgin oil, marked like EV2, was taken from the «Pignatelli Prince S.r.l.» oil-mill, in Monteroduni (IS) while the refined oil, $\mathrm{RO}$, was taken from the "Scipiglia" refinery, in Bisceglie (BA). The all oils were filtered and stored in freezer until the preparation of the preserves.

In order to compare the influence of the thermal treatment and of the storage conditions on the oils in absence of the vegetable each oil was put in two clear-glass jars without eggplants. One of them was subjected to the same thermal treatment as the jars with the eggplants while the other one was used as test sample. So, for every oil the following samples were prepared:

- oil in clear-glass jars with eggplants thermal treated (Covering Oil, CO);

- oil in clear-glass jars thermal treated without eggplants (Thermal Treated Oil, TTO);

- oil test in clear-glass jars (original oil, $\mathrm{OO}$ ).

All the type samples were prepared in double in order to stored them under two different conditions.

\section{2. Methods}

Thermal treatment: the jars with and without the eggplants were immersed in a container with cold water. The container was heated so the water boiled.
The boiling was mantained for 5 min and than the jars were removed and leaved to naturally cool.

Storage of the samples: The samples were stored for 12 months in two different ambiental conditions. The place for the storage were a cellar characterized from constant conditions of temperature $\left(10^{\circ} \mathrm{C}\right)$ and illumination (dark) and a shelf in a room with window in which the temperature and the illumination were variable during the day and the seasons. At the end of the storage test the covering oils were filtrated over $\mathrm{Na}_{2} \mathrm{SO}_{4}$ and kept with the other oil samples in freezer until the moment of the analysis.

Analytical determinations: the acidity, peroxide values and spectrophotometric indexes were determined according to the officials methods included in the EU Regulations (EUROPEAN UNION, 1991).

The acylglycerols compositions were determined by the HRGC analysis using a GC Model 8000 (Fisons Instrument, Rodano, Italy). Data acquisition and processing was carried out with a Chrom-Card software (Thermoquest, Rodano, Italy). A capillary column RTX-65TG (Restek, Bellofonte, PA) with the following specifications: length $15 \mathrm{~m}$, internal diameter $0.32 \mathrm{~mm}$, film thickness $0.50 \mu \mathrm{m}$. The operating conditions of the GC analysis were: on-column injector, flame ionization detector at $380^{\circ} \mathrm{C}$ and $\mathrm{He}$ as carrier gas at pressure of $25 \mathrm{kPa}$. The program of temperature was the following: the temperature at rate was increased of $30^{\circ} \mathrm{C} / \mathrm{min}$ from $80^{\circ} \mathrm{C}$ until $150^{\circ}$ and so mantained for $1 \mathrm{~min}$, than it was again increased at rate of $10^{\circ} \mathrm{C} / \mathrm{min}$ until $365^{\circ} \mathrm{C}$ and so mantained for $15 \mathrm{~min}$. The sample was silanized with pyridine/hexamethyldisilazane/ trimethylchlorosilane 45:35:20 v:v:v.

The phenolic compounds were extracted with pure methanol according to FAVATI et al. (1994) and colorimetrically analysed using the Folin-Ciocalteu reagent (C.Erba, Rodano, Italy), measuring the absorption at $760 \mathrm{~nm}$. The results were expressed in ppm of caffeic acid.

The total chlorophyll content were directly evaluated on the oils by spectrophotometric analysis according to the method proposed by the A.O.A.C (AOAC, 1979). The carotenoids were determined after dilution of the oil in chloroform $(1: 10)$ by spectrophotometry at $460 \mathrm{~nm}$ using $\beta$-carotene (Fluka, Buchs, $\mathrm{CH}$ ) as external standard.

\section{RESULTS AND DISCUSSION}

The analytical determination made at the beginning of the research demonstrated that all the oil samples had the best requisites of quality to be used in the following tests. Initially the values of the acidity and the P.V in all the oils were very low and 
the values found for the spectrophotometric indexes were typical of the class to which the oils belonged (EUROPEAN UNION, 1995). The extra virgin oils, as soon as filtered, and the refined oil showed clear and the first was green while the latter was practically colourless. The total chlorophyll content was 4.0 and $4.9 \mathrm{ppm}$ respectively in the samples EV1 and EV2 while the carotenoids were for both $15 \mathrm{ppm}$ of $\beta$-carotene. In the refined oil the chlorophylls and the carotenoids were in traces and was $1 \mathrm{ppm}$ approximately.

The total Phenols, expressed in ppm of caffeic acid, was 203 for the sample EV1 and 175 for the EV2, while the sample RO presented a very low phenolic content (37 ppm).

As regards the acylglycerol composition the principal difference concerned the total diglycerides; in the refined oil the value found was $10.8 \%$ in comparison with the $2-3 \%$ formed in the extra virgin oils. An other interesting parameter for the evaluation of the quality was the ratio of the 1,2 and 1,3-Diacylglicerols isomers (1,2-DG/1,3-DG). An extra virgin olive oil, as soon as produced, presented the acylglycerols exclusively in form 1,2-DG isomers while the 1,3-DG isomers make up during the storage for inter-glyceridic transposition of the fatty acids. The misure of the 1,3-DG isomers is then representative of a ageing level of the extra virgin olive oil. Also the refine processes determine the formation of the 1,3-DG isomers and in fact in the refined oil all the diacylglicerols were in this form. In this research we have considered only the 1,2-DG/1,3-DG ratio relative to the diacylglicerols with 36 carbon atom (1,2-DG36/1,3-DG36). The initial value of the 1,2-DG36/1,3-GD36 ratio was 0.4 for refined oil and 2.4 and 1.8 respectively for the EV1 and EV2 samples.

The oils were analyzed immediately after the thermal treatment and after 6 and 12 months of storage. In Table I the changes of the P.V and of the spectrophotometric indexes are reported. The P.V. misure was indicative of the oxidation state of the oils and the higher increase was verified in the covering oil relative to the EV1 sample. In fact in the oils stored on the shelf the P.V. value was 32 meq $\mathrm{O}_{2} / \mathrm{kg}$ already after 6 months and also in the samples stored in the cellar the oxidative processes were evident. Instead, in the original oil $(\mathrm{OO})$ and in the thermal treated oil (TTO) relative to the same EV1 sample didn't verify any increase of the P.V. during the storage with the exception of the TTO sample stored on the shelf and analyzed after 12 months. In the EV2 sample the P.V. didn't change significantly in all samples during the storage and the oxidative processes were still limited also after 12 months. In fact the maximum value found of the P.V. was 12 meq $\mathrm{O}_{2} / \mathrm{kg}$ in only two oils. As concern the RO sample the data brought again in table demonstrated that in any oil the P.V. didn't change and the higher increase, from 4 to $9 \mathrm{meq} \mathrm{O}_{2} / \mathrm{kg}$, were recorded in the covering oil stored on the shelf after 12 months.

For it as concern the spectrophotometric indexes, the changes of the $\mathrm{K}_{232}$ values verified during the storage was limited while for the extra virgin oil a significant increase of the $\mathrm{K}_{270}$ and the $\Delta \mathrm{K}$ was recorded. In the extra virgin olive oils stored on the

Table I

The values of the peroxide and of the spectrophotometric indexes determined in the oil during the storage

\begin{tabular}{|c|c|c|c|c|c|c|c|c|c|c|c|c|c|}
\hline \multirow{2}{*}{ Oil types } & \multirow{2}{*}{ Months } & \multicolumn{4}{|c|}{ EV1 } & \multicolumn{4}{|c|}{ EV2 } & \multicolumn{4}{|c|}{ RO } \\
\hline & & ${ }^{*} P . V$. & $\mathrm{K} 232$ & K270 & $\Delta \mathrm{K}$ & ${ }^{*}$ P.V. & $\mathrm{K} 232$ & K270 & $\Delta \mathrm{K}$ & ${ }^{\star} \mathrm{P} . \mathrm{V}$. & $\mathrm{K} 232$ & K270 & $\Delta \mathrm{K}$ \\
\hline $\begin{array}{l}\text { OO } \\
\text { on the shelf } \\
\text { in the cellar }\end{array}$ & $\begin{array}{c}0 \\
6 \\
12 \\
12\end{array}$ & $\begin{array}{l}5 \\
7 \\
7 \\
9\end{array}$ & $\begin{array}{l}1,65 \\
1,70 \\
1,70 \\
1,70\end{array}$ & $\begin{array}{l}0,13 \\
0,25 \\
0,24 \\
0,15\end{array}$ & $\begin{array}{l}0,00 \\
0,01 \\
0,01 \\
0,00\end{array}$ & $\begin{array}{r}7 \\
8 \\
12 \\
11\end{array}$ & $\begin{array}{l}1,89 \\
1,99 \\
1,98 \\
1,90\end{array}$ & $\begin{array}{l}0,11 \\
0,27 \\
0,24 \\
0,17\end{array}$ & $\begin{array}{l}0,00 \\
0,01 \\
0,01 \\
0,00\end{array}$ & $\begin{array}{l}3 \\
6 \\
5 \\
5\end{array}$ & $\begin{array}{l}2,73 \\
2,78 \\
2,89 \\
2,93\end{array}$ & $\begin{array}{l}0,99 \\
0,81 \\
0,79 \\
0,93\end{array}$ & $\begin{array}{l}0,09 \\
0,08 \\
0,07 \\
0,09\end{array}$ \\
\hline $\begin{array}{c}\text { TTO } \\
\text { on the shelf } \\
\text { " } \\
\text { in the cellar }\end{array}$ & $\begin{array}{c}0 \\
6 \\
12 \\
12\end{array}$ & $\begin{array}{r}7 \\
7 \\
13 \\
7\end{array}$ & $\begin{array}{l}1,64 \\
1,72 \\
1,78 \\
1,65\end{array}$ & $\begin{array}{l}0,12 \\
0,23 \\
0,24 \\
0,13\end{array}$ & $\begin{array}{l}0,00 \\
0,01 \\
0,01 \\
0,00\end{array}$ & $\begin{array}{r}10 \\
9 \\
9 \\
11\end{array}$ & $\begin{array}{l}1,91 \\
1,88 \\
1,95 \\
1,90\end{array}$ & $\begin{array}{l}0,14 \\
0,22 \\
0,24 \\
0,13\end{array}$ & $\begin{array}{l}0,00 \\
0,01 \\
0,01 \\
0,00\end{array}$ & $\begin{array}{l}4 \\
6 \\
5 \\
7\end{array}$ & $\begin{array}{l}2,70 \\
2,79 \\
2,89 \\
2,97\end{array}$ & $\begin{array}{l}0,81 \\
0,83 \\
0,77 \\
0,95\end{array}$ & $\begin{array}{l}0,09 \\
0,07 \\
0,07 \\
0,09\end{array}$ \\
\hline $\begin{array}{l}\text { on the shelf } \\
\text { in the cellar }\end{array}$ & $\begin{array}{c}0 \\
6 \\
12 \\
6 \\
12 \\
\end{array}$ & $\begin{array}{l}10 \\
32 \\
47 \\
16 \\
18 \\
\end{array}$ & $\begin{array}{l}1,63 \\
1,67 \\
1,86 \\
1,73 \\
1,88 \\
\end{array}$ & $\begin{array}{l}0,12 \\
0,22 \\
0,24 \\
0,10 \\
0,14 \\
\end{array}$ & $\begin{array}{l}0,00 \\
0,01 \\
0,02 \\
0,00 \\
0,00 \\
\end{array}$ & $\begin{array}{r}9 \\
8 \\
7 \\
10 \\
12 \\
\end{array}$ & $\begin{array}{l}1,83 \\
1,80 \\
1,87 \\
1,93 \\
1,95 \\
\end{array}$ & $\begin{array}{l}0,13 \\
0,23 \\
0,23 \\
0,15 \\
0,16 \\
\end{array}$ & $\begin{array}{l}0,00 \\
0,01 \\
0,02 \\
0,00 \\
0,00 \\
\end{array}$ & $\begin{array}{l}4 \\
4 \\
9 \\
7 \\
6\end{array}$ & $\begin{array}{l}2,99 \\
2,79 \\
2,94 \\
2,96 \\
2,86 \\
\end{array}$ & $\begin{array}{l}0,92 \\
0,89 \\
0,86 \\
0,95 \\
0,97 \\
\end{array}$ & $\begin{array}{l}0,08 \\
0,08 \\
0,08 \\
0,09 \\
0,09\end{array}$ \\
\hline
\end{tabular}

${ }^{*} \mathrm{meq} / \mathrm{O}_{2} / \mathrm{kg}$. 


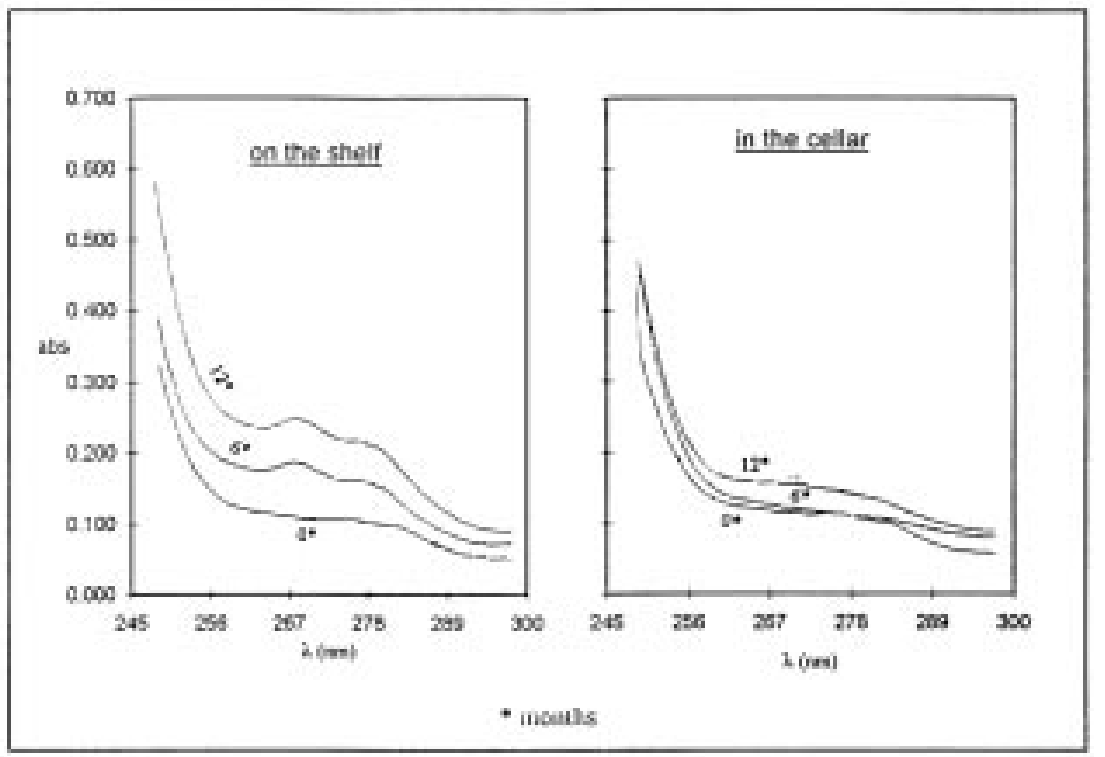

Figure 1

Spectral line around $\lambda 270 \mathrm{~nm}$ of the extra virgin olive oil (EV1) used as covering of the eggplants in relation to the time and the conditions of storage.

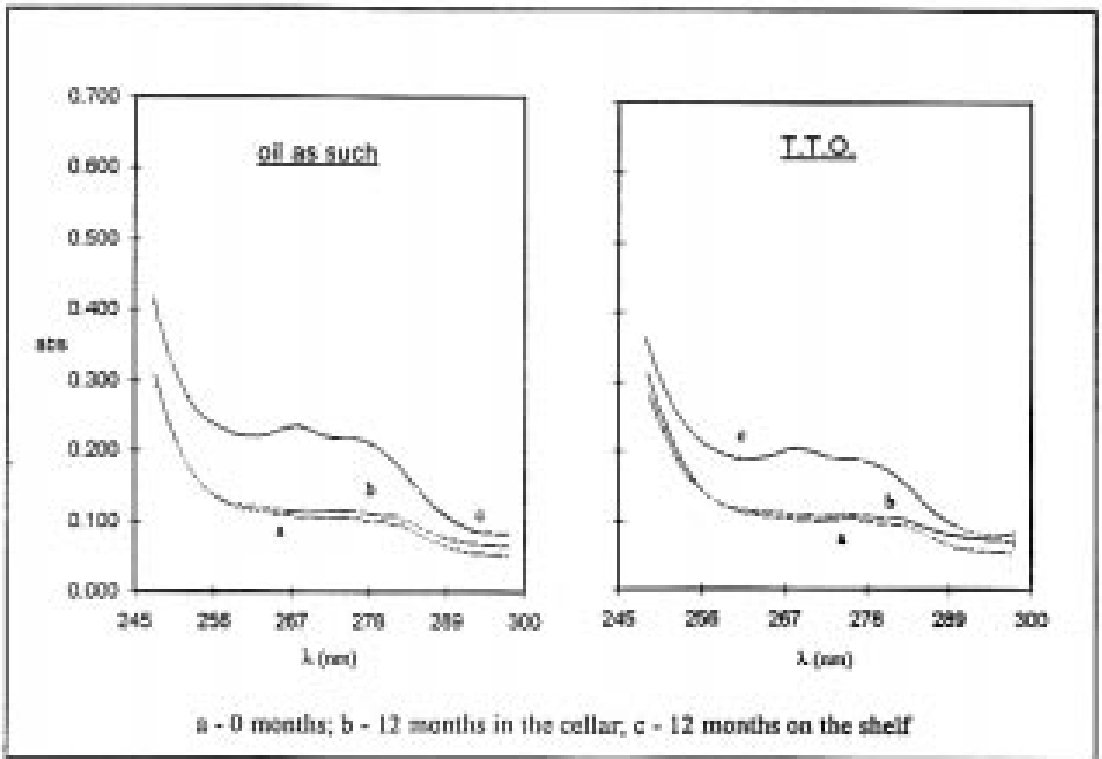

Figure 2

Spectral line around $\lambda 270 \mathrm{~nm}$ of the extra virgin olive oil (EV1) in relation to the time and the conditions of storage.

shelf already after 6 months the $\mathrm{K}_{270}$ values were superior to 0,20 while the $\Delta K$ was 0,01 and 0,02 after 12 months. Instead in the extra virgin olive oils stored in the cellar and in the refined oils the spectrophotometric indexes didn't change as regards the initial values.

The Fig. 1 shows the absorption spectrum around $270 \mathrm{~nm}$ relative to the covering oil of the sample EV1 stored in different condition. The characteristic peak around $270 \mathrm{~nm}$ typical of the refined oils was evident in the extra virgin covering oil already after 6 months when the preserves were stored under light, while when these were stored under dark it didn't appear not even after 12 months.

The spectrum lines relative to the $\mathrm{OO}$ and to the TTO of the EV1 sample, brought again in Fig.2, showed that the formation of the characteristic peak was evident also in the oils without vegetable stored under light. This demonstrated that the light caused the conjugation of the triple bonds independently from the oxidation state of the oil and from the presence or less of the vegetable. The spectrum 
lines relative to the different oil types of the EV2 sample were similar to those reported in the figures 1 and 2.

In Table II the total phenols were reported as mean of the values found for the samples stored on the shelf and in the cellar because no differences were discover between the equivalent oil types. It was evident that in the $\mathrm{OO}$ and in the TTO the total phenols didn't substantially change after the thermal treatment and during the storage. Instead in both extra virgin olive oils used for covering immediately after the thermal treatment the total phenols were drastically reduced and after 12 months these were practically equal to the values found in the refined oil. Therefore it could be suppose that the eggplants, acidified preliminarily with vinegar, have absorbed some phenolic substances subtracting them from the oil.

In Table III the changes in the total chlorophylls and diacylglycerols was reported. In all the extra virgin oils stored under light, with and without the vegetable, the total chlorophylls were reduced in the time, while in the equivalent samples stored in the cellar these didn't change as regards the initial values. In the all refined oils stored as under light as under dark the total chlorophylls didn't decrease and rather in presence of the eggplants a slight increase with the time was noticed.

For it as concern the diacylglycerols analysis it emerged that in all the oils the total diglycerides, expressed in percentage on the total acylglicerols, didn't significantly vary during the storage not even in the samples with the vegetable. This was indicative that in the oils the hydrolytic activity was negligible.
Table II

Total phenols expressed as mean (ppm of caffeic acid) of the values found at different time in the oils stored in the cellar and on the shelf

\begin{tabular}{ccccc}
\hline \multirow{2}{*}{ Samples } & Months & \multicolumn{3}{c}{ Total phenols (ppm of caffeic acid) } \\
\cline { 3 - 5 } & & $\mathbf{0 0}$ & TTO & co \\
\hline EV1 & 0 & 203 & 210 & 58 \\
& 12 & 196 & 194 & 46 \\
EV2 & 0 & 175 & 164 & 40 \\
& 12 & 164 & 162 & 35 \\
RO & 0 & 37 & 36 & 28 \\
& 12 & 35 & 34 & 25 \\
\hline
\end{tabular}

In the extra virgin olive oils the formation of the isomers 1,3-DG36 was verified in all the oil types independently from the storage condition, from the presence or less of the vegetable and from the increase of the P.V. It was evident that the light and the thermal treatment catalysed the isomeric transition. In the refined oil the value of the 1,2-DG36/1,3-DG36 ratio didn't change during the storage in both condition and that showed that ulterior isomerization didn't verify.

\section{CONCLUSIONS}

It was ascertained that in the extra virgin olive oil in the presence of eggplants a drastic reduction of

Table III

Values of the total chlorophylls and diacylglycerols determined in the oils during the storage

\begin{tabular}{|c|c|c|c|c|c|c|c|c|c|c|}
\hline \multirow[b]{2}{*}{ Oil types } & \multirow[b]{2}{*}{ Months } & \multicolumn{3}{|c|}{ EV1 } & \multicolumn{3}{|c|}{ EV2 } & \multicolumn{3}{|c|}{ RO } \\
\hline & & $\begin{array}{c}\text { Total } \\
\text { chlorophylls } \\
\text { ppm }\end{array}$ & $\begin{array}{c}\text { Total } \\
\text { diacylglycerols } \\
\%\end{array}$ & $\begin{array}{c}1,2-1 / 1,3-\mathrm{DG} 36 \\
\text { ratio }\end{array}$ & $\begin{array}{c}\text { Total } \\
\text { chlorophylls } \\
\text { ppm }\end{array}$ & $\begin{array}{c}\text { Total } \\
\text { diacylglycerols } \\
\%\end{array}$ & $\begin{array}{c}1,2-1 / 1,3-\mathrm{DG} 36 \\
\text { ratio }\end{array}$ & $\begin{array}{c}\text { Total } \\
\text { chlorophylls } \\
\text { ppm }\end{array}$ & $\begin{array}{c}\text { Total } \\
\text { diacylglycerols } \\
\%\end{array}$ & $\begin{array}{c}1,2-11,3-D G 36 \\
\text { ratio }\end{array}$ \\
\hline \multicolumn{11}{|l|}{00} \\
\hline & 0 & 4,0 & 2,7 & 2,4 & 4,9 & 3,1 & 1,8 & 1,0 & 10,2 & 0,4 \\
\hline on the shelf & 6 & 1,4 & 2,8 & 1,4 & 1,0 & 3,0 & 0,7 & 0,8 & 11,2 & 0,4 \\
\hline & 12 & 0,7 & 2,2 & 1,0 & 0,5 & 3,0 & 0,5 & 1,1 & 10,5 & 0,4 \\
\hline in the cellar & 12 & 4,2 & 2,4 & 1,4 & 4,8 & 3,0 & 0,8 & 0,9 & 10,0 & 0,4 \\
\hline \multicolumn{11}{|l|}{ TTO } \\
\hline & 0 & 4,1 & 2,4 & 1,8 & 4,9 & 3,1 & 0,8 & 1,1 & 10,1 & 0,4 \\
\hline on the shelf & 6 & 1,2 & 2,5 & 1,3 & 1,0 & 3,1 & 0,6 & 1,1 & 10,7 & 0,4 \\
\hline & 12 & 0,9 & 2,4 & 0,8 & 0,7 & 3,0 & 0,4 & 1,1 & 10,8 & 0,4 \\
\hline in the cellar & 12 & 4,1 & 2,5 & 1,0 & 4,6 & 3,0 & 0,8 & 1,1 & 10,1 & 0,4 \\
\hline \multicolumn{11}{|l|}{$\mathrm{CO}$} \\
\hline & 0 & 4,0 & 2,4 & 1,9 & 4,6 & 3,1 & 1,0 & 1,1 & 10,1 & 0,4 \\
\hline on the shelf & 6 & 1,7 & 2,3 & 1,1 & 1,3 & 3,1 & 0,6 & 1,4 & 10,7 & 0,4 \\
\hline " & 12 & 1,3 & 2,7 & 0,6 & 1,7 & 3,1 & 0,4 & 1,6 & 10,6 & 0,4 \\
\hline in the cellar & 6 & 3,9 & 2,8 & 1,6 & 4,8 & 3,0 & 1,0 & 1,7 & 10,5 & 0,4 \\
\hline & 12 & 4,1 & 2,4 & 1,1 & 4,8 & 3,0 & 0,6 & 1,5 & 10,1 & 0,4 \\
\hline
\end{tabular}


the total phenols was verified immediately after the thermal treatment. The extra virgin oils private of their antioxidant substances were altered at higher rate than the refined oil, probably due to the presence of many substances prooxidants, particularly the chlorophylls.

The changes observed as regards to the $K_{270}$ the $\Delta \mathrm{K}$ and the 1,2-DG36/1,3-DG36 ratio were caused by light and not by the presence of vegetables because similar behaviour was occoursed also in untreated oils.

\section{REFERENCES}

AOAC. (1979). In Official Methods of Analysis $12^{\text {th }}$ ed. Association of Official Analytical Chemist, Washington. DC.

Bizzozero, N. and Carnelli L. (1996). Composizione acidica e trans insaturazione dell'olio di copertura di sgombri e tonni conservati in scatola. Industrie Alimentari 35, 680-683.

Cavallaro, A., Bizzozero, N., Carelli, L. and Renon, P. (1996). Composizione acidica e trans insaturazione dell'olio di copertura di sardine conservate in scatola. Industrie Alimentari 36, 801-805.

Cucurachi, A. (1966). L'olio di oliva di copertura al tonno. Riv. Ital. Sostanze Grasse 43, 335-342.

De Lorenzo, E. (1997). Problematiche relative all'utilizzazione dell'olio d'oliva nelle conserve vegetali. Atti Convegno "L'olio di oliva nelle formulazioni alimentari: aspetti tecnologici ed analitici». Foggia, 30-31 october, p. 135.

European Union. (1991). Regolamento №. 2568/91 L. 248.

Gomes, T., Caponio, F., Baiano, A. and De Pilli, T. (1998). Misura della degradazione ossidativa e idrolitica di olio d'oliva utilizzato come copertura in conserve alimentari. Riv.Ital. Sostanze Grasse 75, 77 - 82.

Favati, B., Caporale, G. and Bertuccioli, M. (1994). Rapid determination of phenol content in extra virgin olive oil. Grasas y Aceites 45, 68 - 70.

Leone, M. and Gambacorta, G. (1997). L'olio di oliva di copertura al tonno. Effetti della migrazione dei lipidi del prodotto di conserva. Aspetti nutrizionali. Atti Convegno L'olio di oliva nelle formulazioni alimentari: aspetti tecnologici ed analitici. Foggia, 30-31 Ottobre, p. 148.

Mucciarella, M.R. and Marsilio, V. (1997). Influenza del processo tecnologico di preparazione e della conservazione sulle caratteristiche chimico-fisiche dell'olio d'oliva vergine extra usato come copertura di conserve vegetali in vasetti di vetro. Riv.ltal. Sostanze Grasse 74, 105 - 112.

Paganuzzi,V., De lorgi, F. and Malerba, A. (1995). Sull'olio d'oliva vergine extra impiegato in conserve alimentari confezionate in contenitori di vetro. Nota 1. Variazione di alcuni parametri chimico-fisici al mutare delle condizioni di produzione e nel corso dell'invecchiamento. Riv.ltal. Sostanze Grasse 72, 529-537.

Paganuzzi, V., Malerba, A. and De Jorgi, F. (1996). Sull'olio d'oliva vergine extra impiegato in conserve alimentari confezionate in contenitori di vetro. Nota 2 . Variazione del contenuto di alcuni componenti minori al mutare delle condizioni di produzione e nel corso dell'invecchiamento. Riv.Ital. Sostanze Grasse 73, 409-415.

Pompei, C. (1978). In Tecnica delle conserve alimentari. (Ed.) CLESAV, Milano, (I). 